\title{
Qualidade de vida na terceira idade
}

Estamos a pouco mais de dois meses do XIV Congresso Brasileiro de Medicina do Esporte, a ser realizado na nossa capital federal. O tema central é "Atividade física e qualidade de vida na terceira idade". Um assunto muito adequado neste "Ano Internacional do Idoso".

A prática regular de exercícios está intimamente relacionada à qualidade de vida do idoso, por uma série de razões.

Uma razão óbvia é que como o exercício físico regular está associado a uma menor possibilidade para o desenvolvimento de uma série de doenças crônicas, como nos mostra uma série de consistentes estudos epidemiológicos, a tendência é que indivíduos que se mantenham fisicamente ativos no decorrer da vida adoeçam menos; se adoecerem, o farão com menos gravidade e se recuperarão mais rapidamente. Devemos nos lembrar que várias doenças crônicas possuem complicações na sua história natural que afetam diretamente a qualidade de vida dos seus portadores. Ainda, a atividade física regular aumenta a duração da vida. Como disse um autor cujo nome não recordamos, o exercício, além de adicionar anos à vida, é capaz também de adicionar vida aos anos.

Muitos idosos vivem em um ciclo vicioso sociocultural que faz com que se limitem em termos de atividade física. Este ciclo vicioso passa pela inatividade física, pelo desenvolvimento de doenças crônicas, pela complicação dessas doenças crônicas e culmina em uma limitação em graus variáveis para executar as tarefas mais simples do cotidiano, como, por exemplo, cuidar da própria higiene. $\mathrm{O}$ quanto este grau de limitação afeta a qualidade de vida nem sempre parece tão óbvio para quem não o possui.

Como muitos idosos - tanto saudáveis como portadores de doenças - estão muito próximos do limiar independência/dependência, mesmo aumentos modestos da capacidade funcional e do limiar anaeróbico induzidos pelo treinamento regular podem resultar em melhoras expressivas da qualidade de vida.

Não devemos, entretanto, limitar o nosso raciocínio somente a fatores ligados à endurance cardiorrespiratória. Ademais desse componente, é igualmente importante para a qualidade de vida do idoso contemplar os outros componentes da aptidão física - força e endurance musculares, flexibilidade e composição corporal. Trabalhar estas qualidades é fundamental para um bom desempenho e melhor aproveitamento em inúmeras situações do dia-a-dia de um idoso - como brincar com um neto, carregar pequenos pesos, fazer compras, passear, etc.

Os "Anos Internacionais" são interessantes sob vários pontos de vista. Provavelmente um deles é chamar a atenção sobre os problemas vividos por determinados grupos humanos e despertar uma discussão no sentido de resolvê-los, ou ao menos atenuá-los. Os problemas enfrentados pelos idosos no Brasil são de naturezas muito diversas; na nossa área de atuação cabe-nos deflagrar discussões que pragmaticamente resultem em benefícios de saúde para esta faixa etária.

No Congresso de Brasília, a maioria dos principais nomes brasileiros na nossa especialidade e alguns colegas internacionais de destaque estarão presentes, discutindo estratégias para melhorar as condições de saúde dos idosos. Deflagrá-las é o nosso papel; começar a colocá-las em ação também; contudo, é importante que a sociedade organizada e os governos em diferentes níveis também contribuam para que o idoso brasileiro tenha um tratamento mais digno e uma melhor qualidade de vida. O momento é agora; temos que trabalhar para isso, pois seria extremamente lamentável chegar ao final do "Ano Internacional do Idoso" sem que nada tenha sido concretamente realizado nesse sentido.

\section{José Kawazoe Lazzoli Editor-Chefe}

